\section{Repurposing of Drugs: Radiological Aspect}

DOI https://doi.org/10.37336/2707-0700-2019-3-7
Repurposing or repositioning of drugs applied in medical practice is the trend under a new adequate unambiguously understood term, although it existed before (for example, applying known drugs for a new purpose) $[5-8,11,12]$. The repurposing of drugs allows to apply well-established schemes for the synthesis of biologically active compounds, to avoid carrying out the scientific research necessary for the introduction of new drugs into medical practice, according to pharmacokinetics, carcinogenicity, acute and chronic toxicity, cardiotoxicity, nephrotoxicity, allergenicity, etc. It is prompt and economic. Repurposing corresponds to the idea of the society existence at the present time - the transition from excessive consumption of resources to their rational application and competent modification/conversion [12].

In oncology, the repurposing programs covers the search for drugs (The Repurposing Drugs in Oncology (ReDO) project), which have antitumor activity or potentiate the antitumor drugs action (among the well-known and widely used drugs nononcologic diseases treatment are acetylsalicylic acid, vitamin D, digoxin, diclofen, indomethacin, clopidogrel, caffeine, melatonin, metformin, pentoxifylline, phenytoin), the analysis of the application possibility of already known antitumor drugs for the treatment of any new nosological forms of non-oncologic diseases (methotrexate, olivomycins, actinomycin) [8, 10-12].

The reason for searching for antitumor properties among other drugs is the fact that the signaling pathways in the cell are characterized by a large number of cross-interactions and some of them can inhibit the tumor cells' proliferation [12]. For re-profiling, the following methods are used [12].

\author{
N.N. Kolotilov', A. Alekseyenko ${ }^{2}$ \\ I.V. Andrushchenko ${ }^{1,3}$, S. Anton ${ }^{4}$ \\ SI "Institute of Nuclear Medicine and \\ Diagnostic Radiology of the National \\ Academy of Medical Sciences of \\ Ukraine"1, Kyiv \\ Martin Health Physician Group Family \\ Medicine ${ }^{2}$, Florida, USA \\ Bogomolets National \\ Medical University ${ }^{3}$, Kyiv \\ EMEX Medical ${ }^{4}$, Geretsried, Germany
}

Blind search or intuitive screening method. At blind search for drugs, the pharmacological and biological molecule properties are not taken into account, the choice of drugs is often based on the intuition of the researcher.

Method based on the search for compounds acting on a specific molecular target.

Method based on the data analysis of the properties and effects of chemical compounds.

Method based on the analysis of changes in the profile of genes' expression under the action of compound.

Method based on the analysis of signaling pathways involved in the drug action. This method is similar to the previous approach, except that the analysis also includes data on the known components of the signaling or metabolic pathways and data on protein-protein interactions to build a cascade specific for a particular disease.

Method based on the analysis of specific mechanisms of disease development. This approach is aimed at identifying the molecular mechanism of the pathology development through the application of an expanded data composition - analysis of protein interaction patterns, signaling pathways, OMIX technology databases - and the drugs' repurposing based on these data. In domestic radiology, these methods are applied in a varying degree [11].

The purposes of the article is to state, within the framework of repurposing and future sudden relevance and demand the information on budget drugs for the long-term maintenance of increased body resistance.

Drugs long-term maintenance of increased radioresistance of the body. In case of prolonged external exposure with a low power, doses of radiation protection drugs are used to prevent the 
long-term effects of radiation (cancer, leukemia, cataracts, reduced life expectancy), to increase the body's resistance to harmful factors of nonradiation-induced nature (rather than reducing mortality from non-developing acute radiation disease). The application of long-term maintenance of increased radioresistance drugs reduces mandatory psycho-emotional stress and related functional disorders [4].

Drugs for long-term maintenance of increased body radioresistance are different from radioprotectors in that the radioprotective effect is not principle for them, they can be used many times and for a long time. With a single irradiation in damaging doses, FUD drugs of this group does not exceed 1.2 [4]. Drugs for long-term maintenance of increased body radioresistance: immunomodulators of exogenous origin (prodigiosan), hormonal drugs (diethylstilbestrol), galenian preparations (extract of Eleutherococcus, lemongrass tincture, tincture of ginseng), vitamin-amino acid complexes (amitetravit, tetrapolevit), metabolitotropy (glutotropy) (vitamin box, amino acid complexes (amitetravit, tetrafolebit), metabolitotrops (riboxin and preparations of succinic acid). Succinic acid (butanedioic acid, ethane-1,2-dicarboxylic acid, Fig. $1)$. Lethal dose $\left(\mathrm{LD}_{50}\right)$ : orally $-2.26 \mathrm{~g} / \mathrm{kg}$ (rats). Food supplement E363. The human body, producing about $200 \mathrm{~g}$ of succinic acid daily, uses it for its own needs.

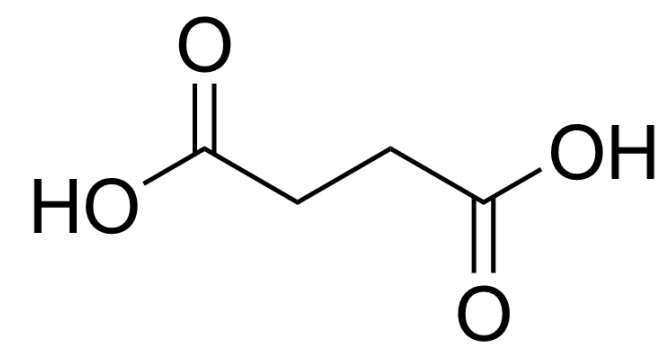

Fig. 1. Succinic acid.

When choosing a drug, preference should be given to tablet forms containing its sodium (most bioavailable) salt and providing a single dose with 1 tablet of a dose of $5-10 \mathrm{mg} / \mathrm{kg}$ body weight, based on sodium succinate, or $3-6 \mathrm{mg} / \mathrm{kg}$ body weight, based on succinic acid [4].

At irradiation in doses that cause bone marrow form of acute radiation disease (light, 1-2 Gy; moderate, 2-4 Gy; severe, 4-6 Gy; extremely heavy, more than $6 \mathrm{~Gy}$ ), on the background of an increase in ambient temperature to $40^{\circ} \mathrm{C}$ and more, the radioprotective efficacy of succinic acid preparations is higher than at normal or lowered ambient temperature [2-4].

Cytoflavin (natural components of the body's metabolism: succinic acid + NADP + riboflavin + riboxin), when applied at a dose of 6.5 Gy in rats, had a radioprotective effect: it increased mainly hematological indicators of nonspecific immunity. Animal survival increased by $40 \%$, and lifetime increased by $30 \%$ compared with the control group [3].

The radioprotective effect of mexidol after a single injection in doses of $5 \mathrm{mg} / \mathrm{kg}$ and $25 \mathrm{mg} /$ $\mathrm{kg}$ exceeds the effect of prophylactic course injection of the drug for 3 weeks in corresponding daily doses. With a single injection of Mexidol, in contrast to the course, the dose increasing to $25 \mathrm{mg} / \mathrm{kg}$ provides a more pronounced preventive radioprotective effect [2].

Riboxin (inosine) is a nucleoside consisting of hypoxanthine bound to the ribose (ribofuranose) residue via the $\beta$-N9-glycosidic bond (Fig. 2) [1, 9]. Metabolic agent, the precursor of ATP.

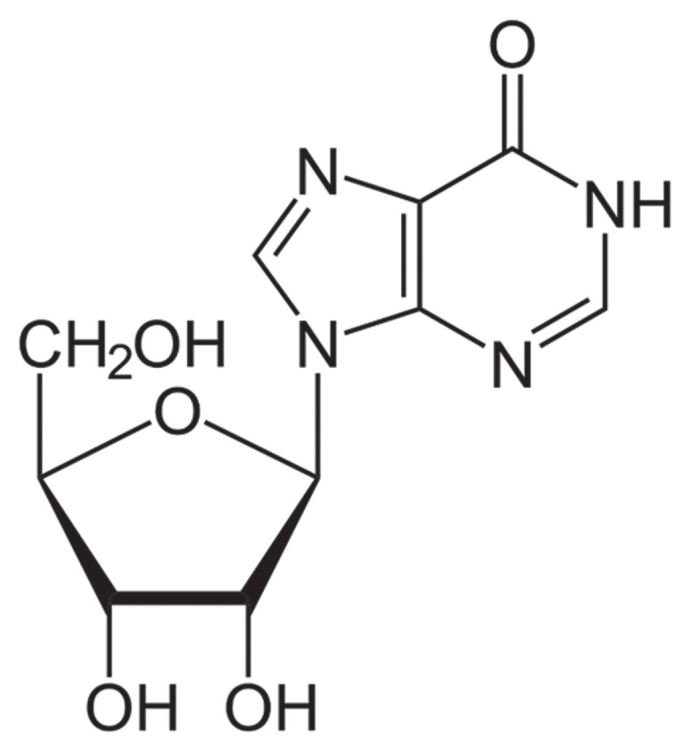

Fig. 2. Riboxin.

Riboxin is a purine derivative. It has an anabolic effect. It activates myocardial metabolism, increases the activity of a series of enzymes of the Krebs cycle, stimulates the nucleotides' synthesis. It inhibits the process of destruction of the ischemic cardiomyocytes' sarcolemma and provides intracellular transport of energy. By improving microcirculation, the drug reduces the zone of necrosis and myocardial ischemia size. It has antihypoxic, metabolic and antiarrhythmic 
effects; increases the myocardium energy balance, improves coronary circulation, prevents the effects of intraoperative renal ischemia. It is directly involved in glucose metabolism and contributes to the activation of metabolism in hypoxic conditions and in the absence of ATP. It activates the metabolism of pyruvic acid to ensure the normal process of tissue respiration, and also contributes to the activation of xanthine dehydrogenase; stimulates the nucleotides' synthesis, enhances the activity of certain enzymes of the Krebs cycle. Penetrating into the cells, it increases the energy via positive effect on the metabolic processes in the myocardium, increases positive inatropic effect in myocardium and contributes to a more complete relaxation of the myocardium in diastole, resulting in an increase in the ACI. It reduces platelet aggregation, activates tissue regeneration (especially the myocardium and gastrointestinal mucosa).

In 2007, the Formulary Committee of the Russian Academy of Medical Sciences classified riboxin as «outdated drugs with unproven efficacy.»

In conditions of prolonged low dose irradiation, riboxin is applied of $0.4 \mathrm{~g}$ dosage, which corresponds to 2 tablets 2 times a day. Riboxin can be used to alleviate the acute effects of shortterm irradiation: administered orally once at a dose of $2.4 \mathrm{~g} 1$ hour before the intended irradiation. The duration of the radioprotective effect of the drug in these conditions is about 2 hours, and repeated use of riboxin in this dose is possible after 24 hours [9].

At the same time, riboxin was positioned as a protection means against the damaging effects of radiation in small and sublethal doses at acute exposure and as a protection means at prolonged irradiation. riboxin was recommended as a protection means for emergency crews when entering an area with high levels of radiation, but the rationale for this recommendation seems to be insufficient [9]. Riboxin in terms of anti-radiation effect manifestation behaves like a hybrid drug that combines the features of oxide- and cytomodulators. The indicator of riboxin anti-radiation efficacy has not yet been determined [9].

\section{Conclusion}

Knowledge of the full real spectrum of drug activity certainly helps to prevent polypragmasia, and is more economically advantageous.
Antiradiation drugs are selected by the body itself, and we only offer them. The possibility of long-term administration is an important advantage of riboxin and succinic acid.

\section{Disclosures}

The authors declare no conflict of interest related to the publication of this article.

\section{Literature}

1. Вартанян Л. П. Радиобиологические основы и перспективы применения рибоксина при лучевой терапии новообразований // Мед. радиология. - 2003. - № 5. - С. 62-66.

2. Гринштейн О. Я. Экспериментальное исследование профилактического радиопротекторного действия мексидола, ЛБК-149 и ' 'альфа"'-токоферола: дис. ... канд. мед. наук: спец. 14.00.25 / Оксана Яковлевна Гринштейн; [Всероссийский научный центр по безопасности биологически активных веществ]. - Старая Купавна, 2002. - 221 с.

3. Джалалов И. М. Биохимические и гематологичекие реакции в механизме повышения радиорезистентности организма под влиянием физической нагрузки: автореф. дис. ... канд. мед. наук: спец. 03.00.04; 14.00.16 / Джалалов Исроил Маликович; [С.-Пб. НИИ физ. культуры, Центр. науч.-исслед. рентгенорадиол. инт]. - СПб., 2000. - 25 с.

4. Ивницкий Ю. Ю. Пути повышения радиорезистентности персонала объектов атомной энергетики / Ю. Ю. Ивницкий, А. Н. Гребенюк, В. Л. Рейнюк, В. И. Легеза // Проблеми безпеки атомних електростанцій і Чорнобиля. - 2005. - Вип. 3, ч. 1. - С. $127-133$.

5. Колотилов Н. Н. Новые компоненты спектра фармакологической активности лекарственных средств, применяемых в оториноларингологии / Н .Н. Колотилов // Журнал вушних, носових і горлових хвороб. - 1999. № 3. - С. 75-79.

6. Колотилов Н. Н. Ближайшие результаты применения нового отечественного йодсодержащего неопиоидного анальгезирующего препарата - амизона при лучевой терапии больных раком гортани / Н. Н. Колотилов, Л. Г. Розенфельд, Т. А. Бухтиарова // Журнал вушних, носових і горлових хвороб. - 1998. № 4. - С. 49-52.

7. Колотілов М. М. Застосування нового вітчизняного імуномодулятора бластену 
при променевій терапії хворих на рак гортані / М. М. Колотілов, Л. Г. Розенфельд, Д. І. Заболотний // Укр. радіол. журнал. - 1998. № 6. - C. 314-315. https://doi.org/10.7868/ S0869803117020126.

8. Корман Д. Перепрофилирование лекарств для онкологии /Д. Корман // Практическая онкология. - 2017. - № 1. - С. 139-158.

9. Рождественский Л. М. Классификация противолучевых средств в аспекте их фармакологического сигнала и сопряженности со стадией развития лучевого поражения /Л. М. Рождественский // Радиационная биология. радиоэкология. - 2017. - № 2. - С. 117-135.

10. Смит Б. Х. Широкий диапазон клинического применения фенитоина / Б. Х. Смит, Дж. Дрейфус; пер. с англ. В. А. Богомольный. - М.: Медицина, 1993. - 272 с.

11. Терновой К. С. Принципы решения медицинских проблем / К. С. Терновой, Л. Г. Розенфельд, Н. Н. Колотилов. - К.: Наук. думка, 1990. - 220 c.

12. Variants and perspectives of drug repurposing for cancer treatment / A. V. Savinkova, E. M. Zhidkova, L. R. Tilova [et al.] // Siberian Journal of Oncology. - 2018. - Vol. 17 (3). - P. 77-87. https:// doi.org/10.21294/1814-4861-2018-17-3-77-87.

\section{REPURPOSING OF DRUGS: RADIOLOGICAL ASPECT}

\author{
N.N. Kolotilov, \\ A. Alekseenko, I.V. Andrushchenko, \\ S. Anton
}

Repurposing or re-positioning of drugs applied in medical practice is a trend under a new adequate and clearly understood term that existed before (for example, application of known drugs for a new purpose).

The purpose of the article is to state, within the framework of repurposing and future sudden relevance and demand, the information on budget drugs for a long-term maintaining of increased body radioresistance.

Drugs for the long-term maintenance of increased body radioresistance are described: riboxin and succinic acid. The possibility of longterm administration is an important advantage of riboxin and succinic acid. The knowledge of the full real spectrum of available drugs, undoubtedly, allows to prevent polypharmacy and conservation of economic resources.

\section{ПЕРЕПРОФІЛЮВАННЯ ЛІКАРСЬКИХ ЗАСОБІВ: РАДІОЛОГІЧНИЙ АСПЕКТ}

\author{
М.M. Колотілов, A. Alekseenko, \\ I.B. Андрющенко, S. Anton
}

Перепрофілювання або перепозиціонування лікарських засобів (ЛЗ), які використовуються в медичній практиці - тренд під новим адекватним однозначно зрозумілим терміном, який існував і раніше (наприклад, використання відомих ЛЗ за новим призначенням).

Мета статті - викласти в рамках перепрофілювання та майбутньої раптової актуальності і потреби інформацію про бюджетні ЛЗ тривалої підтримки підвищеної радіорезистентності організму. Описано ЛЗ тривалої підтримки підвищеної радіорезистентности організму: рібоксин і бурштинова кислота.

Можливість тривалого прийому - важлива перевага рібоксина і янтарної кислоти. Знання повного реального спектру активності ЛЗ, безумовно, дозволяє запобігти поліпрагмазії і економічно більш вигідно.

\section{ПЕРЕПРОФИЛИРОВАНИЕ ЛЕКАРСТВЕННЫХ СРЕДСТВ: РАДИОЛОГИЧЕСКИЙ АСПЕКТ}

\author{
Н.Н. Колотилов, A. Alekseenko, \\ И.В. Андрющенко, S. Anton
}

Перепрофилирование или перепозиционирование лекарственных средств (ЛС), используемых в медицинской практике - тренд под новым адекватным однозначно понимаемым термином, который существовал и ранее (например, использование известных ЛС по новому назначению).

Цель статьи - изложить в рамках перепрофилирования и будущей внезапной актуальности и потребности информацию о бюджетных ЛС длительного поддержания повышенной радиорезистентности организма. Описаны ЛС длительного поддержания повышенной радиорезистентности организма: рибоксин и янтарная кислота. Возможность длительного приёма - важное достоинство рибоксина и янтарной кислоты. Знание полного реального спектра активности доступных ЛС, безусловно, позволяет предотвратить полипрагмазии и экономически более выгодно. 